\title{
Microbiota Alterations and Their Association with Oncogenomic Changes in Pancreatic Cancer Patients
}

\author{
Heidelinde Sammallahti ${ }^{1,2}$, Arto Kokkola ${ }^{2}$, Sama Rezasoltani ${ }^{3}$, Reza Ghanbari ${ }^{4}$, Hamid Asadzadeh Aghdaei ${ }^{5}\left({ }^{\circ}\right.$, \\ Sakari Knuutila ${ }^{1, *}$, Pauli Puolakkainen ${ }^{2,+}$ and Virinder Kaur Sarhadi ${ }^{6,+}$
}

check for updates

Citation: Sammallahti, H.; Kokkola, A.; Rezasoltani, S.; Ghanbari, R.; Asadzadeh Aghdaei, H.; Knuutila, S.; Puolakkainen, P.; Sarhadi, V.K. Microbiota Alterations and Their Association with Oncogenomic Changes in Pancreatic Cancer Patients. Int. J. Mol. Sci. 2021, 22, 12978. https://doi.org/10.3390/ ijms222312978

Academic Editor: Riccardo Masetti

Received: 4 November 2021

Accepted: 25 November 2021

Published: 30 November 2021

Publisher's Note: MDPI stays neutral with regard to jurisdictional claims in published maps and institutional affiliations.

Copyright: (c) 2021 by the authors. Licensee MDPI, Basel, Switzerland. This article is an open access article distributed under the terms and conditions of the Creative Commons Attribution (CC BY) license (https:/ / creativecommons.org/licenses/by/ $4.0 /)$.
1 Department of Pathology, Faculty of Medicine, University of Helsinki, 00014 Helsinki, Finland; heidelinde.sammallahti@helsinki.fi

2 Department of Surgery, Abdominal Center, Helsinki University Hospital and University of Helsinki, 00290 Helsinki, Finland; arto.kokkola@hus.fi (A.K.); pauli.puolakkainen@hus.fi (P.P.)

3 Foodborne and Waterborne Diseases Research Center, Research Institute for Gastroenterology and Liver Diseases, Shahid Beheshti University of Medical Sciences, Tehran P.O. Box 1985717411, Iran; samasoltani70@gmail.com

4 Digestive Oncology Research Center, Digestive Diseases Research Institute, Tehran University of Medical Science, Tehran P.O. Box 1411713135, Iran; r.ghanbari98@gmail.com

5 Basic and Molecular Epidemiology of Gastrointestinal Disorders Research Center, Research Institute for Gastroenterology and Liver Diseases, Shahid Beheshti University of Medical Sciences, Tehran P.O. Box 1985717411, Iran; hamid.assadzadeh@gmail.com

6 Department of Oral and Maxillofacial Diseases, Helsinki University Hospital and University of Helsinki, 00290 Helsinki, Finland; virinder.sarhadi@helsinki.fi

* Correspondence: sakari.knuutila@helsinki.fi

+ These authors contributed equally to this work.

Abstract: Pancreatic cancer (PC) is an aggressive disease with a high mortality and poor prognosis. The human microbiome is a key factor in many malignancies, having the ability to alter host metabolism and immune responses and participate in tumorigenesis. Gut microbes have an influence on physiological functions of the healthy pancreas and are themselves controlled by pancreatic secretions. An altered oral microbiota may colonize the pancreas and cause local inflammation by the action of its metabolites, which may lead to carcinogenesis. The mechanisms behind dysbiosis and PC development are not completely clear. Herein, we review the complex interactions between PC tumorigenesis and the microbiota, and especially the question, whether and how an altered microbiota induces oncogenomic changes, or vice versa, whether cancer mutations have an impact on microbiota composition. In addition, the role of the microbiota in drug efficacy in PC chemo- and immunotherapies is discussed. Possible future scenarios are the intentional manipulation of the gut microbiota in combination with therapy or the utilization of microbial profiles for the noninvasive screening and monitoring of PC.

Keywords: pancreatic cancer; pancreatic ductal adenocarcinoma; microbiota; dysbiosis; oncogenomics; mutations; inflammation; drug response; bacterial metabolites

\section{Introduction}

Pancreatic cancer (PC) is an aggressive malignancy with a high mortality and poor prognosis. Even though the world-wide incidence is relatively low (2.3\% of new cancer cases per year), PC accounts for $4.7 \%$ of cancer-related deaths [1]. In the US and Europe, with a $3 \%$ incidence, PC accounts for $7-9 \%$ of cancer-related deaths, which represents the third and fourth most common cause of neoplastic deaths, respectively [2,3]. The incidence of PC in Central Africa and Central Asia is the lowest worldwide; however, some developing countries such as Iran, have similar incidences to Western countries [4,5].

PC often has no specific symptoms and is detected at a locally advanced or metastatic stage when it is too late for a curative treatment. In addition to this, PC tends to develop 
resistance to chemotherapy, which leads to recurrence and death in most cases [6]. Although the five-year survival rate in the US has improved slightly $(2-3 \%$ to $10 \%)$ in the past decades [7], due to improved treatment regimens and more efficient screening, it is still very low. The mortality rate of PC has remained more or less stagnant or even increased over the past decades in the US and Europe [8] and PC is projected to become the second most common cause of cancer-related death in the US by 2030 [9].

Histologically, PCs can be grouped into exocrine and neuroendocrine tumors. About 95\% of PCs are exocrine tumors, which originate from pancreatic exocrine cells composed of acinar and ductal cells. Pancreatic ductal adenocarcinoma (PDAC) is the most prevalent class of PC accounting for over $90 \%$ of all pancreatic malignancies [10]. PDAC most commonly arises from pancreatic intraepithelial neoplasms (PanINs), that gradually develop into malignancy by accumulating somatic mutations.

Risk factors associated with the development of PCs include advanced age (median 71 years), gender (males have a slightly higher incidence than females), a family history of PC, cigarette smoking, heavy alcohol consumption, chronic pancreatitis, obesity, type 2 diabetes mellitus and diet [11,12]. About $5 \%-10 \%$ of PCs are associated with inherited risk factors that include familial pancreatic cancer, familial adenomatous polyposis, familial atypical multiple mole melanoma, and Peutz-Jeghers syndrome [13,14].

The investigation of cytogenetic, genetic, and epigenetic changes in PC has led to a better understanding of tumorigenesis and has opened up new possibilities of early diagnosis and disease monitoring in cancer. Mutations in KRAS are the most frequent genetic changes, followed by mutations in tumor suppressors TP53, SMAD4 and CDKN2A [15] that cause changes in multiple molecular pathways, resulting in cancer development. However, the tumorigenesis of PC has not been fully uncovered and no efficient treatment has been found.

Over the past decade, the human microbiome has become a hot topic in biomedical research, as the development of high throughput methods has facilitated the simultaneous detection of hundreds of different species of microorganisms in a single sample [16]. The gut microbiome is an essential factor in several physiological processes, including host energy metabolism, an inflammatory state, gut permeability, and peptide hormone secretion [17]. In cancer research, the significance of microorganisms in the development of certain malignancies, like Helicobacter pylori in gastric cancer and human papillomavirus (HPV) in cervical cancer, is widely recognized [18]. It has become clear that microorganisms can (1) participate in tumorigenesis, (2) influence the host immune response, and (3) alter microbial and host metabolism [19]. Apart from these tumorigenic qualities, microbes may be exploited as anticancer agents by their ability to infect and survive within the human body. They could be used to deliver bioactive molecules like toxins to tumor cells, thus killing them. Clostridium and Salmonella, for example, have been shown to survive within tumors [20].

Due to their physical proximity, malignancies of the gastrointestinal tract (GIT) are prone to being influenced by the gut microbiota. In our previous studies, we were able to show associations between different kinds of GIT neoplasms and certain gut microbiota profiles [21,22]. In the case of colorectal cancer (CRC), for example, studies on the gut microbiome have led to a better understanding of CRC development and the identification of microbiome biomarkers, and they have provided insight into the influence of microbiota on cancer therapy [23]. The role of the microbiome in PC, however, has not yet been studied that well, and there are still controversies regarding its impact on PC tumorigenesis, progression, and drug resistance [24].

In this review, we elucidate the latest findings of microbiota research in PC. Special focus is laid on possible connections between the microbiome, oncogenic changes, and PC. Identifying such associations will help in understanding the role of microorganisms in the tumorigenesis mechanisms of PC, and could have an impact on early diagnosis, more effective treatment, and the improvement of survival rates in PC patients. 


\section{Genomic Characteristics of Pancreatic Cancer}

PC is marked by a highly complex karyotype with multiple structural and numerical chromosome abnormalities, including recurrent aberrations involving known oncogenes and tumor suppressors [25]. Although the mutational landscape of PC is characterized by numerous somatic copy number alterations (CNAs) and gene mutations, only four genes play a major role and are affected in most sporadic PDAC cases. These include the oncogene KRAS and the tumor suppressors TP53, SMAD4 and CDKN2A [15]. One of the earliest events in tumorigenesis that is detectable in almost all PDAC precursor lesions is KRAS oncogene activation, which might be considered as the molecular feature of this malignancy [26]. The Cancer Genome Atlas Network (TCGA) published an integrated genomic characterization of PDAC patients, utilizing a multiplatform approach that included genomics, transcriptomics, and proteomics [15]. Mutated KRAS was detected in $93 \%$ of PDAC patients, with the G12D allele in $41 \%$, the G12V allele in $27 \%$, and the G12R allele in $19 \%$ of cases. In $5 \%$ of the patients, multiple distinct KRAS mutations were detected, while in $7 \%$ of the cases with wild-type $K R A S$, mutations in other RAS pathway genes, or alternative oncogenic drivers were found. The frequencies of TP53, SMAD4, and CDKN2A mutations were $72 \%, 32 \%$, and $30 \%$ of the cases, respectively. Less frequently mutated genes were the oncogenes GATA6, GNAS, AKT2, FGFR1, MYC, BRAF and MDM2, chromatin modification genes ARID1A, PBRM1, MLL3 and MLL4, tumor suppressors PTEN and DNA damage-repair genes BRCA1, BRCA2, ATM and PALB2 [15].

\section{The Microbiome in Pancreatic Health}

The pancreas plays an important role in metabolism through the secretions of its exocrine and endocrine glands. While the exocrine gland controls digestion by producing pancreatic juice (digestive enzymes and sodium bicarbonate), the endocrine gland secretes islet peptide hormones to maintain glucose homeostasis [27]. A healthy pancreas is pivotal in controlling the gut microbiota and reciprocally the gut microbiota has a key impact on pancreatic function [28]. Studies on mouse models have shown that antimicrobial peptides secreted by the pancreas control the composition and diversity of the gut microbiota, and, as a consequence, protect against inflammation. The cathelicidin-related antimicrobial peptide (CRAMP), produced by pancreatic endocrine $\beta$-cells, destroys unwanted intestinal microbes by permeabilizing the bacterial membrane [29]. A preclinical study demonstrated that the absence of CRAMP due to impaired exocytosis leads to an alteration in the gut microbiota and bacterial overgrowth in pancreatic cells, and further, to intestinal inflammation and death. Supplementation of CRAMP, however, prevented this bacterial overgrowth and inflammation, which confirms the influence of the pancreas on the gut microbiota [30].

On the other hand, certain metabolites produced by gut bacteria affect pancreatic function. In a study on mice, butyrate, a short-chain fatty acid (SCFA) produced by intestinal bacteria, has been shown to induce the expression of CRAMP in pancreatic $\beta$-cells [31]. Likewise, acetate, another SCFA metabolite of gut bacteria, induced insulin secretion in rats via a microbiome-brain $\beta$-cell axis [32]. This mutual interaction between the gut microbiota and the pancreas is thus important both in health and disease. Bacterial imbalance or dysbiosis may lead to a dysfunctional pancreas and result in disease, and reciprocally pancreatic disease may cause intestinal dysbiosis (Figure 1).

The gut microbiota is, nevertheless, not the only potential influencer of pancreatic health. Contrary to previous assumptions, the pancreas itself is not sterile and has its own microbiota. The presence of bacterial DNA in pancreatic tissue has been reported in $76 \%$ of PDAC patients and 15\% of healthy individuals [33]. Microbes are thought to migrate from the duodenum to the pancreas through the pancreatic duct. A comparison of the microbiota from different gastrointestinal sites has shown an overlap of the pancreatic and duodenal microbiome both in PC patients and in healthy controls, affirming that pancreatic bacteria may migrate from the intestine. The pancreatic microbiota have been reported to be very diverse and include certain taxa typically detected in the oral cavity. Moreover, the pancreatic bacterial diversity in PC patients has been found to vary significantly from 
that of healthy controls [34]. The presence of bacterial DNA in pancreatic tissue samples was also confirmed by Thomas et al., but they did not find significant differences in genus richness or diversity between cancerous and noncancerous tissue [35].

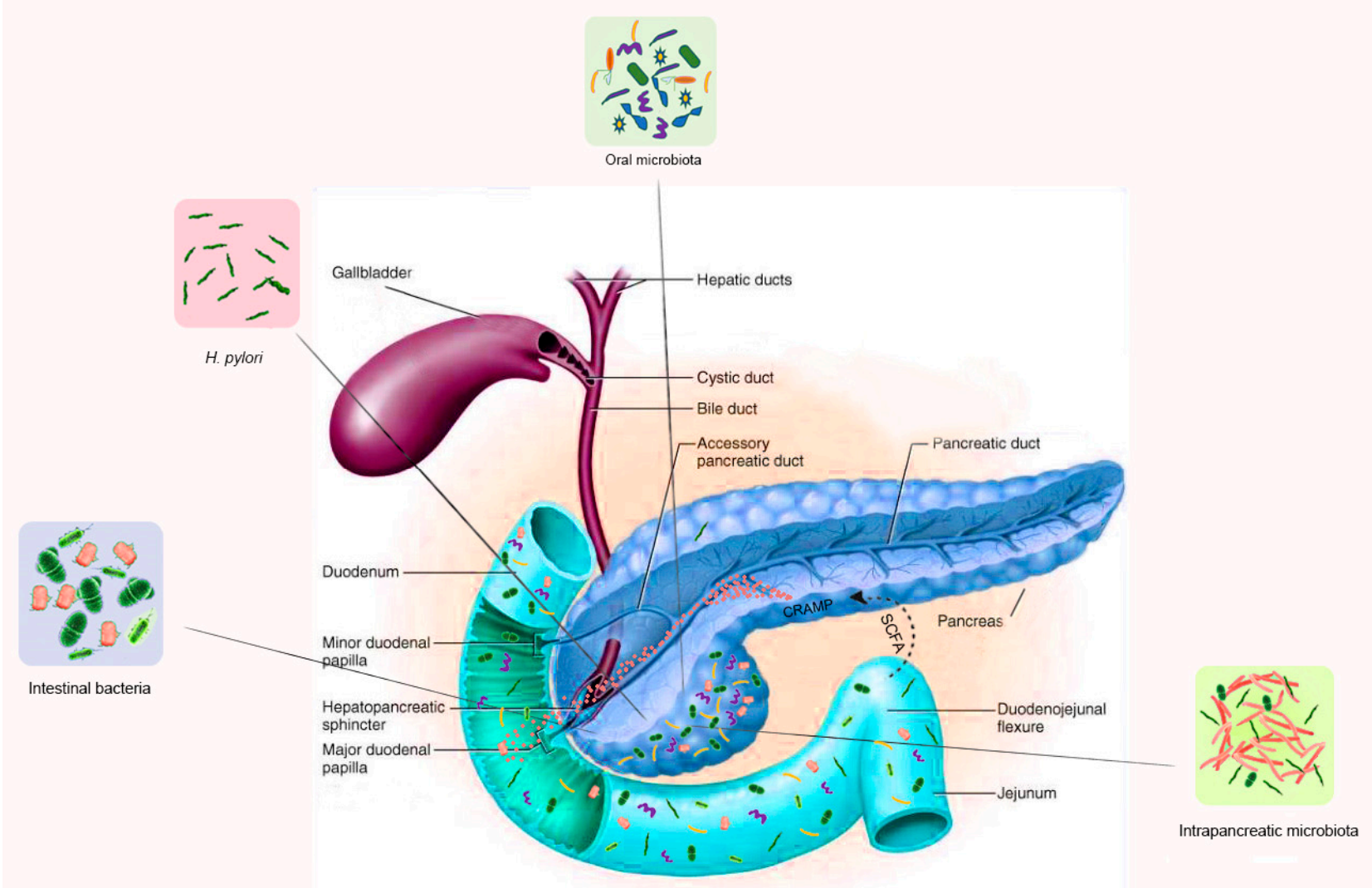

Figure 1. The interplay or cross talk between specific microbiota and pancreatic function, in both health and disease. The short chain fatty acids (SCFA), produced by intestinal bacteria, induce the expression of cathelicidin-related antimicrobial peptides (CRAMP, red dots) in pancreatic $\beta$-cells. Impaired CRAMP secretion renders the gut microbiota dysbiotic and results in bacterial overgrowth. The pancreas is colonized under normal physiological conditions by microbes via the pancreatic duct, oral-intestinal route, mesenteric venous drainage, and mesenteric lymphatic drainage.

Pushalkar et al. have demonstrated migration of oral fluorescently labeled Enterococcus faecalis to the pancreas via the intestine, with a higher level of migration in PDAC mice compared to noncancerous mice [17]. Interestingly, in an experiment with germ-free mice, the pancreas was not colonized by bacteria under normal physiological conditions [35]. Besides the pancreatic duct, alternative ways of colonization of the pancreas have been suggested, including oral, mesenteric venous drainage, and mesenteric lymphatic drainage routes [36]. These partly contradictory findings illustrate that the questions regarding the origin and significance of the intrapancreatic microbiome are not fully resolved. Further studies on larger cohorts are needed for clarification.

\section{Microbiota Alterations in PC}

In addition to influencing the physiological functions of the pancreas, microbial dysbiosis can also enhance inflammation and affect tumorigenic processes, such as cellular proliferation, invasion, metastasis, angiogenesis, and immune modulation [37]. Besides genetic and environmental factors, the oncogenic microbiome, or oncobiome, is one of the regulators of the hallmarks of cancer $[38,39]$. In addition to the local tumorigenic effects, alterations in microbiota may also exert hormone-like, long-distance effects on different 
organs [40]. The following subsections provide an overview of microbial alterations in different parts of the gastrointestinal tract and their possible significance in PC. A graphic summary of these alterations is shown in Figure 2.

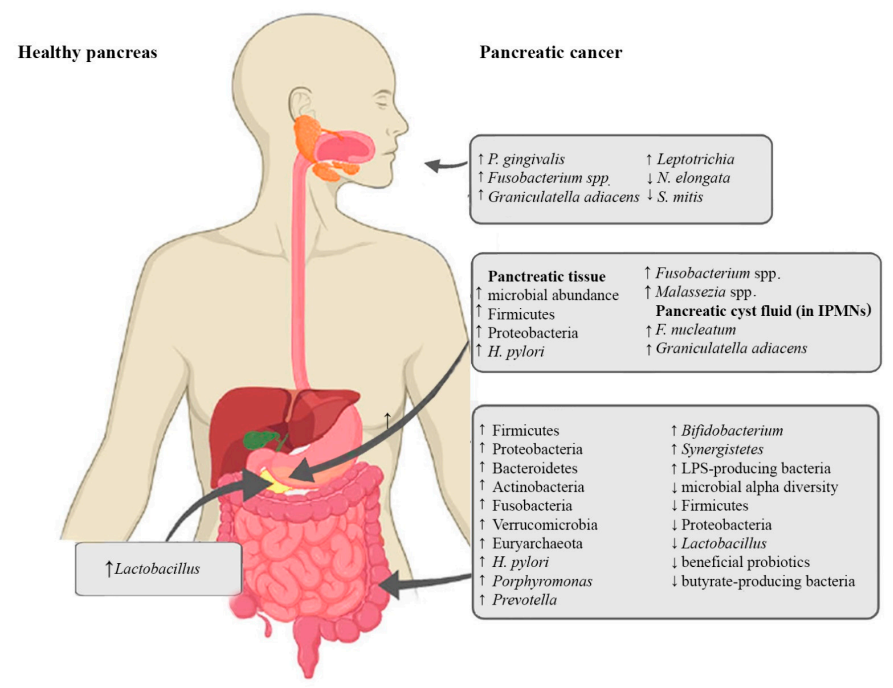

Figure 2. Alterations of oral, pancreatic and intestinal microbiota in PC. $\uparrow$ indicates an increase, $\downarrow$ indicates a decrease.

\subsection{Oral Microbiota and PC}

Several studies have shown an association of oral bacterial dysbiosis with PC tumorigenesis [41-43]. The spread of oral microbes to the pancreas via translocation or dissemination has been discussed in the previous section [44,45]. Periodontal disease, a condition linked to alterations in oral bacteria, has been related to an increased risk of PC [46]. Poor oral health, pathogenic oral flora, periodontal disease, and tooth loss are well-established independent risk factors for PDAC [41].

Unique oral microbiota profiles have been associated with PDAC in several studies. PC was associated with significantly increased abundances of the oral bacteria Porphyromonas gingivalis [47-49], Fusobacterium [49], Graniculatella adiacens [50] and Leptotrichia [48,49] and significantly decreased abundances of Neisseria elongata and Streptococcus mitis [50], amongst others. Combinations of certain microbes, like N. elongata and S. mitis, or the increased ratio of Leptotrichia to Porphyromonas were found to significantly differentiate PC patients from healthy controls and were thus suggested as potential predictive biomarkers for the early detection of PC, especially since saliva sampling is noninvasive and very easy to arrange $[48,50]$.

\subsection{Pancreatic Microbiota and PC}

Preclinical models have shown that the microbial abundance in pancreatic tumor tissue is up to a thousand times higher than in healthy pancreatic tissue [17,51]. The PDAC microbiota has been profiled in several studies, with partly similar, and partly differing results $[17,34,42,52-55]$. The first pathogen to be detected in pancreatic tumor tissue and associated with PC was H. pylori [56]. H.pylori DNA was reported in the pancreatic tissue of $75 \%$ of PDAC patients, in $60 \%$ of patients with chronic pancreatitis, but in none of the healthy controls [57]. In addition, the abundance of Fusobacterium spp., an oral pathogen, was found to be significantly increased in PDAC tissue compared to controls and was associated with a worse prognosis [34,42]. Lactobacillus, on the other hand, was more common in healthy controls than in PDAC patients [34]. An increased abundance of Firmicutes and Proteobacteria, which are also the most prominent phyla of the healthy gut, has been observed in several studies in PC tissue as compared to healthy pancreatic tissue $[36,55,56]$. An enrichment of the fungal microbe Malassezia spp. in PDAC tumor 
tissue has also been reported [52]. In addition to that, pancreatic cyst fluid was found to contain its own unique microbiome [58]. An increased abundance of the oral bacteria Fusobacterium nucleatum and Granulicatella adiacens was detected in the pancreatic cyst fluid of IPMNs compared to non-IPMN pancreatic cystic neoplasia. Since IPMNs can develop into invasive PC, the results point to the possible pathogenicity of these species and underscores the likelihood of bacterial colonization from the oral cavity [59].

\subsection{The Intestinal Microbiota and PC}

As the pancreas is connected to the intestine through the pancreatic duct, it is obvious that the gut microbiota can influence the pancreas and vice versa [36]. To investigate the relationship between gut microbial dysbiosis and PC, the intestinal tissue microbiota, as well as the fecal microbiota of PC patients have been studied. Clear associations of a unique gut microbiome profile with PDAC were shown in several studies [56,60-63], and a significant decrease in the microbial alpha diversity was observed in PDAC cancer patients compared to healthy controls $[56,61,64]$.

Summarizing the main findings, $H$. pylori infection in the upper gastrointestinal tract has been associated with an increased risk of developing PDAC $[65,66]$. H. pylori is believed to have an impact on carcinogenesis by promoting cell proliferation [67]. Significantly increased abundances of bacteria belonging to the phyla Bacteroidetes, Firmicutes [61,68], Proteobacteria, Actinobacteria, Fusobacteria, Verrucomicrobia [34,36,69], the genera Porphyromonas, Prevotella, Bifidobacterium [34] and Synergistetes, as well as the archaeal phylum Euryarchaeota [17], have been reported in PC in comparison to healthy controls. Other changes in the gut microbiota reported in PC, were decreased abundances of Firmicutes, Proteobacteria [61] and Lactobacillus [34]. Ren et al. noted an increase in the abundance of potentially pathogenic lipopolysaccharide (LPS)-producing bacteria and a decrease in the abundance of beneficial probiotics and butyrate-producing bacteria in PC patients [61]. Results of different studies are partly similar, but partly contradictory, indicating that larger studies will be needed for establishing a clearer profile of the PDAC gut microbiome.

\section{Microbiota in Pancreatic Inflammation, Oncogenesis and Tumor Immunity}

Inflammation of the pancreas plays a key role in the development of pancreatic cancer. One cause of pancreatic inflammation is a dysbiotic oral, gastric, or intestinal microbiota that can cause an overgrowth of harmful bacteria. This can lead to epithelial barrier breaches and the migration of bacteria to the pancreas. Continual colonization of the pancreas by dysbiotic bacteria results in persistent inflammation and promotes cancer development [24].

Microbial products or metabolites support tumor growth by maintaining inflammation and by immune modulation [37]. Bacterial products such as LPS, SCFAs, lipoproteins, lipopeptides, as well as CpG DNA and single- or double-stranded DNA, can induce immune suppression by binding to pattern recognition receptors (PPR) and by activating Toll-like receptors (TLR). This promotes tumor growth by immune evasion, especially during early carcinogenesis [70]. LPS-induced TLR signaling is also thought to help in maintaining inflammation in PC [37].

Inflammation can also contribute to PC development through its oncogenic effect. Chronic inflammation in pancreatic tissue can trigger KRAS oncogenic mutation in insulinpositive endocrine cells and induce the differentiation of epithelial cells, resulting in PDAC [69]. KRAS is mutated in 93\% of PC cases [15] and despite being a common mutation, the activation of KRAS can still require hyperstimulation from LPS-driven inflammation [61]. The activated KRAS can further advance carcinogenesis by activating the nuclear factor kappa B (NF- $\mathrm{kB})$ pathway [71].

A distinct tumor microbial profile (Pseudoxanthomonas/Streptomyces/Saccharopolyspora/Bacillus clausii) has been linked with longer survival of PC patients. Moreover, a higher diversity of tumor microbiota was found associated with higher tumor infiltration of T-cells. Notably, 
the tumor bacterial profile of long-term survivors was associated with higher infiltrating $\mathrm{CD}^{+} \mathrm{T}$-cells expressing granzyme $\mathrm{B}$ and better cytotoxic T-cell responses [53].

\section{The Microbiota and Drug Response in PC}

PC patients are often treated with gemcitabine-based chemotherapy [72] and they frequently develop chemoresistance and reduced drug sensitivity [73]. It has been shown that the microbiota plays an important role in the therapeutic efficacy in PC [74]. In CRC mouse models, Geller and colleagues observed that the enzyme cytidine deaminase, produced by Gammaproteobacteria (especially Mycoplasma hyorhinis), metabolizes gemcitabine into its inactive form. Gemcitabine resistance was induced by intratumor Gammaproteobacteria and abrogated by antibiotic treatment [33]. Moreover, they detected bacterial DNA, mostly belonging to Gammaproteobacteria in $76 \%$ of the tumors of PDAC patients. Therefore, they suggested that antibiotics could be coadministered with gemcitabine therapy to prevent the development of drug resistance [33]. Similarly, Fusobacterium nucleatum was shown to promote chemoresistance in CRC [75]. However, the gut microbiota can also have positive effects in chemotherapy. For example, Lactobacillus plantarum culture supernatant had a favorable influence on the treatment of colorectal cancer cells with 5 -fluorouracil by increasing its chemosensitivity [76]. Likewise, Enterococcus hirae and Barnesiella intestinihominis improved the therapeutic efficacy of cyclophosphamide by facilitating immunomodulatory effects [77].

Immunotherapeutic approaches in PC that are currently under investigation include immune checkpoint inhibitors (ICIs), vaccine therapy, adoptive cell transfer, myeloidtargeted therapy, immune agonist therapy and combinations with chemoradiotherapy or other molecularly targeted agents [78,79]. Bacteria can exert both positive or negative influences on the immune response and immunotherapies. For example, Bacteroidetes spp. were shown to activate Th1 immune responses, and Listeria monocytogenes changed tumorassociated macrophages from the immunosuppressive M2 phenotype to the antitumor M1 phenotype [74]. The immune response in cancer therapy was improved by the inhibition of regulatory T cells (Tregs) through Bifidobacterium adolescentis, Enterococcus faecium, Collinsella aerofaciens and Parabacteroides merdae [74]. The gut microbiota has been shown to increase the efficacy of blockade therapy of programmed cell death 1 (PD-1) protein and its ligand, programmed cell death ligand 1 (PD-L1) [80]. On the contrary, the anticancer immune response increased and the tumor burden was reduced by depletion of the gut microbiota through oral gavage antibiotics treatment in a mouse model of PC [81].

The use of gut microbes in combination with immunotherapies has been suggested for the future [74]. However, their mechanisms in enhancing or attenuating the efficacy of immunotherapies need to be identified. Through fecal microbiota transplant (FMT) or supplementation with certain prebiotics, probiotics, or antibiotics, the gut microbial composition could be manipulated to enhance host anticancer immunity and combat drug resistance [80]. Moreover, the gut microbiota could be used as a biomarker for drug efficacy, treatment response and drug side effects [74].

\section{Associations of Bacterial Metabolites with Carcinogenic and Oncogenomic Changes in PC}

7.1. Bacterial Metabolites and Their Effect on the Pancreas and PC

Metabolites derived from gut bacteria can affect factors and processes involved in tumorigenesis [37]. Due to the microbial imbalance in PC, bacterial metabolites are largely dysregulated and may act in a pro- or anticarcinogenic way [61]. SCFAs are metabolites mainly stemming from the bacterial fermentation of nondigestible carbohydrates in the colon. They include acetate, butyrate, propionate and lactate, amongst others. Apart from serving as an energy source for colonocytes and other cells, they have an impact on the composition of the microbiome in the colon by regulating the $\mathrm{pH}$ and modulating the immune system [37]. In addition, they can modulate epigenetics, gene expression, cell proliferation, and apoptosis [82]. In PC, butyrate was found to have an antiproliferative 
effect on cultured PDAC cells [83]. In the study by Ren et al., dysbiosis in PC was associated with a decrease in butyrate-producing bacteria [61].

Other bacterial metabolites that are dysregulated in PC are polyamines [84]. Polyamines are polycationic alkylamines that are involved in multiple oncogenic and cell signaling pathways [85]. Since they are essential for cell growth, their absence leads to cell-cycle arrest [86]. A large number of gut bacteria synthesize, accumulate, or utilize polyamines [87]. In a mouse model of PC, serum polyamine levels were significantly elevated and associated with cell proliferation and tumor progression [88]. However, in a study on human PDAC, the transport pathways of some polyamines were upregulated, whereas the biosynthesis and the transport pathways of other polyamines were downregulated in tumor tissue [61]. Polyamines can be utilized in targeted therapy or as biomarkers for the early detection of PC $[86,88]$.

LPS is another bacterial component influencing pancreatic cancer. As part of the outer membrane of Gram-negative bacteria, LPS is released into the surrounding environment both during membrane vesicle trafficking and after destruction of the cell wall [89]. LPS plays an important role in the development of PC since it mediates and maintains Toll-like receptor (TLR)-induced inflammation. Levels of LPS-producing bacteria are found to be increased in PC [61].

\subsection{Bacterial Metabolites and Their Effect on Cancer Mutations}

In addition to influencing the tumorigenic processes, bacterial metabolites can have an impact on cancer mutations. In a recent study using a mouse model of intestinal cancer with gain-of-function mutations in Tpr53, Kadosh et al. observed that mutated p53 functioned as a tumor suppressor in the proximal part of the gut (duodenum and jejunum) by disrupting the Wnt pathway, causing a decrease in cell proliferation [90]. On the contrary, in the distal region of the gut (ileum and colon), it acted in an oncogenic gain-of-function manner by activating Wnt signaling and consequently inducing neoplasia. The reason for this opposing function was found to be related to the gut microbiome. Since bacteria are sparse in the proximal but abundant in the distal region of the intestine [91], the authors suspected that certain gut microbial metabolites caused the switch of the mutant p53 from having a tumor-suppressive role to an oncogenic role. They performed a metabolite screen by treating p53-mutated mouse jejunal organoids with several bacterial metabolites known to be associated with tumorigenesis. They found that the bacterial metabolite gallic acid significantly increased Wnt activity and cell proliferation. Gallic acid, a metabolite of L. plantarum and Bacillus subtilis in the human gut, was found to reverse the Wnt-suppressive function of mutated p53 by epigenetic mechanisms [90]. This study elegantly showed how a bacterially derived metabolite can influence the effect of cancer mutations. To our knowledge, comparable studies have not been conducted on PC yet. It is, however, likely that similar mechanisms act in pancreatic carcinogenesis.

\subsection{Dysbiosis and Oncogenomic Changes in PC}

One of our objectives for this review was to search for possible associations between the microbiota and oncogenomics. Are cancer mutations caused by certain microbiota patterns, or vice versa, are certain microbiota profiles induced by cancer mutations? In CRC, associations between an altered microbiota profile and CRC driver gene mutations have been reported. Higher abundances of Herbaspirillum and Catenibacterium were associated with mutations in NRAS and TP53, respectively, while lower abundances of Barnesiella were associated with mutated RAS genes [92]. Moreover, several bacterial species involved in CRC tumorigenesis, such as Escherichia coli, Bacteroides fragilis, E. faecalis and Campylobacter jejuni are reported to exert carcinogenic or genotoxic effects (reviewed in [93]).

Comparable studies in PC are scarce and direct associations between dysbiosis and cancer mutations have not been reported to our knowledge. However, certain deductions regarding a possible association can be made from some of the studies. A study investigating the associations of different oncogenomic features of PC with the presence of 
Fusobacterium spp. in tumor tissue, found the presence of Fusobacterium in tumors to be linked with a worse prognosis. However, no associations between the tumor Fusobacterium status and the molecular features typical for PC, including mutations in KRAS, NRAS, $B R A F$, and PIK3CA, epigenetic changes, and mi-R21, mi-R31, or mi-R143 expression levels, could be found [42].

Studies on bacterial infections linked to PC and their possible mechanistic pathways have suggested, that microbes like $P$. gingivalis may have a carcinogenic impact by regulating miRNA expression and thus influencing important immunologic and cancer-related signaling pathways, which may happen in a far-distanced manner [44]. Moreover, the carcinogenic action of bacteria has been summarized as interference in the cell cycle through the induction of DNA damage, mutations, aberrant cell signaling, immune evasion, inflammation, aberrant miRNA expression, and the induction of epigenetic changes [94]. In this regard, the significance of $H$. pylori and P. gingivalis in PC have been emphasized [94]. It was hypothesized that the enzyme peptidyl arginine deiminase, secreted by oral bacteria P. gingivalis, Tannerella forsythia and Treponema denticola, could be responsible for $p 53$ and KRAS point mutations in PC through the degradation of arginine [95]. This has, however, not been experimentally proven. In studies on human PC cell lines and xenografts in mouse models, exposure to $P$. gingivalis increased the tumorigenic behavior of cancer cells. The authors postulated $P$. gingivalis to synergize with mutant KRAS or other oncogenic factors and thus promote tumorigenesis [96].

In several studies, mutated KRAS has been suspected to influence microbiota or microbiota to influence KRAS function and signaling [17,35]. Pushalkar et al. investigated the influence of the pancreatic microbiota on tumorigenesis in PDAC using a mouse model with mutant Kras and Tp53. They found that PDAC was associated with a distinct gut and pancreatic microbiota that promotes oncogenesis by immune suppression, and implied, that expression of mutant Kras might have an impact on the composition and diversity of the gut and pancreatic microbiota [17]. In a similar study that investigated the impact of the host microbiota on PC tumorigenesis both in a mouse model and in human pancreatic tumor tissue, Thomas et al. observed that the gut microbiota accelerated carcinogenesis in the pancreas. By analyzing transcriptomic changes, they found procarcinogenic genes to be upregulated in the presence of the gut microbiota, while anticarcinogenic pathways were upregulated in the absence of the gut microbiota. However, the carcinogenic effect of the gut microbiota seemed to be independent of the Kras mutational status [35].

In a study on different subtypes of PDAC, an increased abundance of Acinetobacter, Pseudomonas and Sphingopyxis were associated with KRAS signaling, DNA replication, and other PC-related pathways in the basal-like subtype [97]. Moreover, Guo et al. found a correlation between microbial $\beta$-diversity and host genetics, indicating that host genetic variation can influence the microbiome composition, which may play a role in PC carcinogenesis. For example, genetic variation linked to a lower antimicrobial immune response (affecting genes involved in interferon- $\gamma$-mediated infection-related signaling pathways) could cause dysbiosis and expansion of a pathogenic, cancer-promoting microbiota [97].

Chakladar et al. analyzed the relationship between the intrapancreatic microbiota, immunological changes, and gene expression signatures in 187 PDAC patients [54]. They found that the tumor abundance of 13 bacterial species, mostly belonging to the phylum Proteobacteria and especially Gammaproteobacteria, correlated with a poor prognosis and cancer progression. Smokers and males were especially found to harbor a cancer-promoting microbiota and had a worse prognosis. A. baumannii and Mycoplasma hyopneumoniae were associated with increased oncogenic gene expression signatures in smokers, and E. coli and M. hyponeumoniae were linked to CNA [54]. The main findings of the studies reporting possible associations of the microbiota with oncogenomic changes, and the analytical methods used are summarized in Table 1. 
Table 1. Reviews and studies suggesting associations between microbial and oncogenomic changes in PC.

\begin{tabular}{|c|c|c|c|c|c|c|c|}
\hline Reference & Study Population & Specimen & Analytical Methods & Main Findings & Microbial Changes & Oncogenomic Changes & $\begin{array}{l}\text { Possible Associations } \\
\text { between the Microbiota } \\
\text { and Oncogenetics in PC }\end{array}$ \\
\hline Mitsuhashi 2015 [42] & Human PDAC vs. HC & Pancreatic & $\begin{array}{l}\text { TaqMan Gene } \\
\text { Expression Assay }\end{array}$ & $\begin{array}{l}\text { Fusobacterium spp. is } \\
\text { present in } 8.8 \% \text { of PC } \\
\text { tissue and independently } \\
\text { associated with a worse } \\
\text { prognosis; } F \text {. spp. could } \\
\text { be used as a prognostic } \\
\text { biomarker of PC. }\end{array}$ & $\begin{array}{l}\uparrow F \text {. spp. detected in } \\
8.8 \% \text { of PC tissue } \\
\text { specimens. }\end{array}$ & $\begin{array}{l}\text { Mutations in KRAS, } \\
\text { NRAS, BRAF or PIK3CA, } \\
\text { epigenetic changes or } \\
\text { mi-R21, mi-R31 or } \\
\text { mi-R143 expression } \\
\text { levels. }\end{array}$ & $\begin{array}{l}\text { No significant association } \\
\text { was found between the } \\
\text { Fusobacterium species status } \\
\text { and molecular alterations of } \\
\text { pancreatic cancers. }\end{array}$ \\
\hline Shirazi et al. 2020 [94] & NA & NA & $\begin{array}{l}\text { Review aiming to } \\
\text { evaluate bacterial } \\
\text { agents as cancer } \\
\text { biomarkers }\end{array}$ & $\begin{array}{l}\text { Bacteria can influence the } \\
\text { cell cycle through } \\
\text { inflammation, aberrant } \\
\text { cell signaling, immune } \\
\text { evasion, DNA damage } \\
\text { and mutations, aberrant } \\
\text { miRNA expression and } \\
\text { epigenetic changes. }\end{array}$ & $\begin{array}{l}\text { H. pylori and P. gingivalis } \\
\text { are associated with PC. }\end{array}$ & $\begin{array}{l}\text { DNA damage, } \\
\text { mutations, expression } \\
\text { of certain microRNAs, } \\
\text { and epigenetic effects }\end{array}$ & $\begin{array}{l}\text { Bacteria involved in } \\
\text { carcinogenesis cause } \\
\text { alterations in the cell cycle } \\
\text { by the induction of DNA } \\
\text { damage, mutations, } \\
\text { expression of microRNA } \\
\text { and epigenetic effects, } \\
\text { amongst others. H. pylori } \\
\text { and P. gingivalis cause } \\
\text { inflammation and } \\
\text { P.gingivalis may } \\
\text { regulate miRNAs. }\end{array}$ \\
\hline Ögrendik 2017 [95] & Human PC & Oral & $\begin{array}{l}\text { Hypothesis based on } \\
\text { earlier findings }\end{array}$ & $\begin{array}{l}\text { P. gingivalis, Tannerella } \\
\text { forsythia and Treponema } \\
\text { denticola secrete } \\
\text { peptidylarginine } \\
\text { deaminase, which might } \\
\text { cause } p 53 \text { and KRAS point } \\
\text { mutations. }\end{array}$ & $\begin{array}{l}\text { P. gingivalis, } \\
\text { T. forsythia and T. } \\
\text { denticola are major } \\
\text { pathogens of CPO. }\end{array}$ & Mutations in $p 53, K R A S$ & $\begin{array}{l}\text { Bacterial peptidylarginine } \\
\text { deaminases originating } \\
\text { from P. gingivalis, T. forsythia } \\
\text { and T. denticola might cause } \\
\text { p53 and KRAS point } \\
\text { mutations by the } \\
\text { degradation of arginine. } \\
\text { CPO has been associated } \\
\text { with orodigestive cancer. }\end{array}$ \\
\hline
\end{tabular}


Table 1. Cont

\begin{tabular}{|c|c|c|c|c|c|c|c|}
\hline Reference & Study Population & Specimen & Analytical Methods & Main Findings & Microbial Changes & Oncogenomic Changes & $\begin{array}{l}\text { Possible Associations } \\
\text { between the Microbiota } \\
\text { and Oncogenetics in PC }\end{array}$ \\
\hline $\begin{array}{l}\text { Gnanasekaran et al. } \\
2020 \text { [96] }\end{array}$ & $\begin{array}{l}\text { Human (PC cell lines, } \\
\text { xenograft model) }\end{array}$ & Pancreatic & $\begin{array}{l}\text { Gene expression } \\
\text { analysis by qRT-PCR, } \\
\text { detection of } P \text {. gingivalis } \\
\text { by RT PCR }\end{array}$ & $\begin{array}{l}\text { Exposure to } P \text {. gingivalis } \\
\text { increases tumorigenic } \\
\text { behavior in PC cell lines. }\end{array}$ & $\begin{array}{l}\text { P. gingivalis influences } \\
\text { PC progression. }\end{array}$ & Mutant $K R A S$ & $\begin{array}{l}\text { P.gingivalis may synergize } \\
\text { with mutant KRAS to } \\
\text { promote tumorigenesis. }\end{array}$ \\
\hline $\begin{array}{l}\text { Pushalkar et al. } \\
2018 \text { [17] }\end{array}$ & $\begin{array}{l}\text { Human PDAC, mouse } \\
\text { (KPC or KRASG12D } \\
\left.\text { Trp53 }{ }^{\mathrm{R} 172 \mathrm{H}} \mathrm{Pdx} \mathrm{Pde}^{\mathrm{Cre}}\right)\end{array}$ & $\begin{array}{l}\text { Pancreatic (mouse); } \\
\text { pancreatic and fecal } \\
\text { (human) }\end{array}$ & $\begin{array}{l}\text { 16S rRNA gene } \\
\text { sequencing }\end{array}$ & $\begin{array}{l}\text { The PDAC microbiome } \\
\text { promotes oncogenesis by } \\
\text { immune suppression via } \\
\text { TLR; this could be used as } \\
\text { a therapeutic target. }\end{array}$ & $\begin{array}{l}\uparrow \text { Probacteria } \\
\text { (Pseudomonas, } \\
\text { Elizabethkingia) in } \\
\text { human PC tissue, is } \\
\text { associated with } \\
\text { advanced disease; } \\
\uparrow \uparrow \text { Proteobacteria, } \\
\text { Synergistetes, } \\
\text { Euryarchaeotain the } \\
\text { feces of PC patients. }\end{array}$ & Mutated $\operatorname{Kras}(\mathrm{G} 12 \mathrm{D})$ & $\begin{array}{l}\text { The composition and } \\
\text { diversity of the gut and } \\
\text { pancreatic microbiota may } \\
\text { be influenced by oncogenic } \\
\text { Kras expression. }\end{array}$ \\
\hline $\begin{array}{l}\text { Thomas et al. } \\
2018 \text { [35] }\end{array}$ & $\begin{array}{l}\text { Human PDAC vs. CP } \\
\text { and HC; mouse } \\
\text { (Kras(G12D)/PTEN }^{\text {lox } /+} \text { ) }\end{array}$ & Pancreatic & $\begin{array}{l}\text { 16S rRNA gene } \\
\text { sequencing, RNAseq of } \\
\text { human PDAC } \\
\text { xenografts in mice }\end{array}$ & $\begin{array}{l}\text { The pancreatic microbiota } \\
\text { in PC accelerates } \\
\text { carcinogenesis. No } \\
\text { distinct microbiota profile } \\
\text { is significantly associated } \\
\text { with PC. Gut bacteria } \\
\text { exert a long-distance } \\
\text { effect on PC } \\
\text { carcinogenesis. Bacterial } \\
\text { colonization of the } \\
\text { pancreas is not a } \\
\text { physiological process. }\end{array}$ & $\begin{array}{l}50 \% \text { of PC mice } \\
\text { harbored } \\
\text { intrapancreatic bacteria. } \\
\uparrow \text { Acinetobacter, Afipia, } \\
\text { Enterobacter, } \\
\text { Pseudomonas in human } \\
\text { PC tissue. }\end{array}$ & $\begin{array}{l}\text { Mutated Kras } \\
\text { (Kras(G12D)/ } \\
\text { PTENlox/+ mouse } \\
\text { model) }\end{array}$ & $\begin{array}{l}\text { The gut microbiota } \\
\text { accelerates pancreatic } \\
\text { carcinogenesis in a mouse } \\
\text { model of PC. Many genes } \\
\text { involved in carcinogenesis } \\
\text { are differently expressed } \\
\text { depending on the gut } \\
\text { microbiota state. The } \\
\text { microbial effect seems to be } \\
\text { independent of the Kras } \\
\text { mutational status. The } \\
\text { pancreatic microbiota is not } \\
\text { correlated } \\
\text { with carcinogenesis. }\end{array}$ \\
\hline $\begin{array}{l}\text { Riquelme et al. } \\
2019 \text { [53] }\end{array}$ & $\begin{array}{l}\text { Human PDAC STS vs. } \\
\text { PDAC LTS }\end{array}$ & Pancreatic & $\begin{array}{l}\text { 16S rRNA gene } \\
\text { sequencing }\end{array}$ & $\begin{array}{l}\text { Higher } \alpha \text {-diversity in the } \\
\text { LTS tumor microbiome; } \\
\text { predominant taxa could } \\
\text { be used as biomarkers for } \\
\text { the prediction of LTS; } \\
\text { PDAC microbiome } \\
\text { composition influences } \\
\text { host immune response. }\end{array}$ & $\begin{array}{l}\text { Enrichment of } \\
\text { proteobacteria } \\
\text { (Pseudoxanthomanas), } \\
\text { Actinobacteria } \\
\text { (Streptomyces, } \\
\text { Saccharopolyspora), } \\
\text { Bacillus clausii in LTS } \\
\text { compared to STS. }\end{array}$ & $\begin{array}{l}\text { No genomic differences } \\
\text { in PDAC LTS vs. STS. }\end{array}$ & $\begin{array}{l}\text { No genomic differences in } \\
\text { stage matched PDAC LTS } \\
\text { compared to STS. }\end{array}$ \\
\hline
\end{tabular}


Table 1. Cont

\begin{tabular}{|c|c|c|c|c|c|c|c|}
\hline Reference & Study Population & Specimen & Analytical Methods & Main Findings & Microbial Changes & Oncogenomic Changes & $\begin{array}{l}\text { Possible Associations } \\
\text { between the Microbiota } \\
\text { and Oncogenetics in PC }\end{array}$ \\
\hline $\begin{array}{l}\text { Chakladar et al. } \\
2020 \text { [54] }\end{array}$ & Human PDAC & Pancreatic & $\begin{array}{l}\text { Next generation RNA } \\
\text { sequencing }\end{array}$ & $\begin{array}{l}\text { The PC tumor microbiota } \\
\text { is associated with gene } \\
\text { expression dysregulation, } \\
\text { metastasis and immune } \\
\text { suppression. A worse } \\
\text { prognosis in males and } \\
\text { smokers is linked to the } \\
\text { presence of } \\
\text { cancer-promoting } \\
\text { microbiota profiles. }\end{array}$ & $\begin{array}{l}\text { A. ebreus } \\
\text { (Betaproteobacteria) } \\
\text { correlated with immune } \\
\text { dysregulation and poor } \\
\text { prognosis, } \\
\text { Gammaproteobacteria } \\
\text { correlated with } \\
\text { increased metastasis. } A \text {. } \\
\text { baumannii and } M \text {. } \\
\text { hypneumoniae associated } \\
\text { with smokers. }\end{array}$ & $\begin{array}{l}\text { Oncogenic gene } \\
\text { expression signatures, } \\
\text { CNA; } \\
\text { Deletions at the 9q13 } \\
\text { locus. }\end{array}$ & $\begin{array}{l}\text { An increased abundance of } \\
\text { A. baumannii and } M \text {. } \\
\text { hypneumoniae is associated } \\
\text { with an increase of } \\
\text { oncogenic and decrease of } \\
\text { tumor suppressive and } \\
\text { immune signatures in } \\
\text { smokers; E. coli abundance } \\
\text { is correlated with CNA; } M \text {. } \\
\text { hyopneumoniae is } \\
\text { significantly correlated with } \\
\text { deletions at } 9 \text { q13 (potential } \\
\text { tumor suppressor) } \\
\text { in smokers. }\end{array}$ \\
\hline Guo et al. 2021 [97] & $\begin{array}{l}\text { Human (different } \\
\text { PDAC subtypes) }\end{array}$ & Pancreatic & $\begin{array}{l}\text { Metagenomic } \\
\text { sequencing, RNA-seq }\end{array}$ & $\begin{array}{l}\text { Analysis of the tumor } \\
\text { microbiome in different } \\
\text { subtypes of PDAC: the } \\
\text { microbial profile in } \\
\text { basal-like PDAC was } \\
\text { highly associated with } \\
\text { carcinogenesis, possibly } \\
\text { through the induction of } \\
\text { pathogen-related } \\
\text { inflammation. Host } \\
\text { genetics influence the } \\
\text { composition of the tumor } \\
\text { microbiome. }\end{array}$ & $\begin{array}{l}\uparrow \text { Acinetobacter, } \\
\text { Pseudomonas and } \\
\text { Sphingopyxis in } \\
\text { basal-like tumors }\end{array}$ & KRAS signaling & $\begin{array}{l}\text { Acinetobacter, Pseudomonas } \\
\text { and Sphingopyxis are } \\
\text { associated with carcinogenic } \\
\text { gene-expression, KRAS } \\
\text { signalling, DNA replication } \\
\text { and other PC-related } \\
\text { pathways. Bacterial LPS can } \\
\text { hyperstimulate KRAS and } \\
\text { initiate carcinogenesis. A } \\
\text { microbial procarcinogenic } \\
\text { effect is caused by } \\
\text { continuous inflammation } \\
\text { rather than direct } \\
\text { mutagenesis. Host genetics } \\
\text { participate in shaping the } \\
\text { tumor microbiome. }\end{array}$ \\
\hline
\end{tabular}

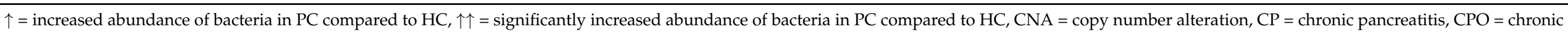
periodontitis, $\mathrm{HC}=$ healthy controls, LTS = long-term survivors, NA = not applicable, $\mathrm{PDAC}=$ pancreatic ductal adenocarcinoma, $\mathrm{PC}=$ pancreatic cancer, $\mathrm{STS}=$ short-term survivors 


\section{Conclusions}

This review aimed to investigate the impact of the microbiota on PC and the associations between dysbiosis and oncogenomic changes. We investigated the interactions between the microbiota and pancreas in health and disease. In the healthy pancreas, antimicrobial peptides secreted by the pancreas control the gut microbiota composition, while SCFAs produced by gut microbes induce the secretion of substances like CRAMP or insulin by the pancreas. In PC, the microbiota is dysbiotic in different parts of the gastrointestinal tract. Oral pathogenic bacteria are translocated via intestinal and other routes to the pancreas, where they cause inflammation, which furthermore develops to cancer. The microbiota also has an influence on drug efficacy during cancer therapy, with the ability to either boost or hamper chemo- or immunotherapies. Metabolites of a dysbiotic microbiota affect tumorigenesis in pro- or anticarcinogenic ways. They may induce and maintain the state of inflammation, have an impact on oncogenic and cell-signaling pathways, drive the carcinogenic transformation of premalignant cells or influence tumor cell proliferation. Bacterial metabolites may also change the function of genes through epigenetic mechanisms, as in the example of gallic acid that switches mutated TP53 from tumor-suppressive to oncogenic.

No direct association between the microbiota and cancer mutations in PC has been detected so far. However, several connections have been observed or hypothesized. Fusobacterium was associated with a worse prognosis in PC, while no associations with oncogenomic features of PC were found. The oral pathogen $P$. gingivalis increased the tumorigenic behavior of PDAC cells by inducing cell proliferation and activating cancer signaling pathways. This was speculated to happen through a synergy between $P$. gingivalis and other oncogenic factors such as mutant KRAS. P. gingivalis was also hypothesized to advance PDAC by altering miRNA expression and to cause point mutations in KRAS and $p 53$, amongst others. Procarcinogenic genes were found to be upregulated in the presence of the PDAC microbiota. Furthermore, associations between the PDAC microbiota and KRAS-signaling, and associations between certain bacterial species with CNA were detected. Conversely, looking at the influence of PDAC mutations on microbiota, mutated KRAS was postulated to influence the gut and pancreatic microbiota composition and diversity, and certain host-genetic variations were proposed to cause dysbiosis and lead to cancer development. These results illustrate the complex relationship between the microbiota and PC tumorigenesis. The PDAC microbiota profiles that have been generated so far are partly contradictory, and larger studies would be needed to define the microbial landscape of PDAC more clearly. Moreover, studies combining the profiling of both the microbiota and oncogenomics would help to clarify the relationship between these crucial players in PC tumorigenesis. This could contribute to understanding the larger picture of PC formation and progression. The development of noninvasive screening methods based on the oral or stool microbiota could lead to earlier detection and better surveillance of PC. Additionally, the microbiota could be utilized as a predictive marker of treatment response, and treatment outcomes could be improved by microbial depletion of the gut through antibiotics or manipulation of the gut microbiota through FMT, pre- or probiotics to introduce a beneficial microbiota that promotes drug efficacy.

Author Contributions: H.S.: writing—original draft preparation. A.K., S.R., R.G., H.A.A., S.K., P.P. and V.K.S.: writing-review and editing. S.R.: illustration. All authors have read and agreed to the published version of the manuscript.

Funding: This review was funded by HUS Abdominal Center research and project funding.

Institutional Review Board Statement: Not applicable.

Informed Consent Statement: Not applicable.

Acknowledgments: Open access funding provided by University of Helsinki. Illustrations were created with BioRender.com. The authors would like to sincerely thank Raha Rezasoltani for helping to generate the figures. 
Conflicts of Interest: The authors declare no conflict of interest.

\section{References}

1. Sung, H.; Ferlay, J.; Siegel, R.L.; Laversanne, M.; Soerjomataram, I.; Jemal, A.; Bray, F. Global cancer statistics 2020: GLOBOCAN estimates of incidence and mortality worldwide for 36 cancers in 185 countries. CA Cancer J. Clin. 2021, 71, 209-249. [CrossRef]

2. Siegel, R.L.; Miller, K.D.; Fuchs, H.E.; Jemal, A. Cancer Statistics, 2021. CA Cancer J. Clin. 2021, 71, 7-33. [CrossRef]

3. European Cancer Information System. Available online: https://ecis.jrc.ec.europa.eu/explorer.php? $\$ 0-0 \$ 1-A 11 \$ 2-A 11 \$ 4$ -1,2\$3-19\$6-0,85\$5-2008,2008\$7-7\$CEstByCountry\$X0_8-3\$X0_19-AE27\$X0_20-No\$CEstBySexByCountry\$X1_8-3\$X1_1 9-AE27\$X1_-1-1\$CEstByIndiByCountry\$X2_8-3\$X2_19-AE27\$X2_20-No\$CEstRelative\$X3_8-3\$X3_9-AE27\$X3_19-AE2 7\$CEstByCountryTable\$X4_19-AE27 (accessed on 10 May 2021).

4. Ahmadloo, N.; Bidouei, F.; Omidvari, S.H.; Ansari, M.; Mosalaei, A.; Mohammadianpanah, M. Pancreatic Cancer in Southern Iran. Iran. Red Crescent Med. J. 2010, 12, 624-630.

5. Hadizadeh, M.; Padashi, M.; Alizadeh, A.H.M.; Zali, M.R. Clinical, Laboratory Biomarkers and Imaging Findings of Pancreatic Adenocarcinoma in Iran. Asian Pac. J. Cancer Prev. APJCP 2014, 15, 4349-4352. [CrossRef]

6. Ansari, D.; Tingstedt, B.; Andersson, B.; Holmquist, F.; Sturesson, C.; Williamsson, C.; Sasor, A.; Borg, D.; Bauden, M.; Andersson, R. Pancreatic cancer: Yesterday, today and tomorrow. Future Oncol. 2016, 12, 1929-1946. [CrossRef]

7. Howlader, N.; Noone, A.M.; Krapcho, M.; Miller, D.; Brest, A.; Yu, M.; Ruhl, J.; Tatalovich, Z.; Mariotto, A.; Lewis, D.R.; et al. SEER Cancer Statistics Review, 1975-2017; National Cancer Institute: Bethesda, MD, USA, 2020.

8. Carioli, G.; Malvezzi, M.; Bertuccio, P.; Boffetta, P.; Levi, F.; La Vecchia, C.; Negri, E. European cancer mortality predictions for the year 2021 with focus on pancreatic and female lung cancer. Ann. Oncol. 2021, 32, 478-487. [CrossRef]

9. Rahib, L.; Smith, B.D.; Aizenberg, R.; Rosenzweig, A.B.; Fleshman, J.M.; Matrisian, L.M. Projecting cancer incidence and deaths to 2030: The unexpected burden of thyroid, liver, and pancreas cancers in the United States. Cancer Res. 2014, 74, $2913-2921$. [CrossRef]

10. Pishvaian, M.J.; Brody, J.R. Therapeutic Implications of Molecular Subtyping for Pancreatic Cancer. Oncology 2017, 31, 159-166.

11. Mizrahi, J.D.; Surana, R.; Valle, J.W.; Shroff, R.T. Pancreatic cancer. Lancet 2020, 395, 2008-2020. [CrossRef]

12. Klein, A.P. Pancreatic cancer epidemiology: Understanding the role of lifestyle and inherited risk factors. Nat. Rev. Gastroenterol. Hepatol. 2021, 18, 493-502. [CrossRef] [PubMed]

13. Solomon, S.; Das, S.; Brand, R.; Whitcomb, D.C. Inherited Pancreatic Cancer Syndromes. Cancer J. 2012, 18, 485-491. [CrossRef]

14. Zhou, B.; Xu, J.W.; Cheng, Y.G.; Gao, J.Y.; Hu, S.Y.; Wang, L.; Zhan, H.X. Early detection of pancreatic cancer: Where are we now and where are we going? Int. J. Cancer 2017, 141, 231-241. [CrossRef]

15. Raphael, B.J.; Hruban, R.H.; Aguirre, A.J.; Gupta, M.; Getz, G.; Meyerson, M.; Fei, S.S.; Loher, P.; Rigoutsos, I.; Telonis, A.G.; et al. Integrated Genomic Characterization of Pancreatic Ductal Adenocarcinoma. Cancer Cell 2017, 32, 185-203.e13. [CrossRef] [PubMed]

16. NIH Human Microbiome Portfolio Analysis Team. A review of 10 years of human microbiome research activities at the US National Institutes of Health, Fiscal Years 2007-2016. Microbiome 2019, 7, 31. [CrossRef] [PubMed]

17. Pushalkar, S.; Hundeyin, M.; Daley, D.; Zambirinis, C.P.; Kurz, E.; Mishra, A.; Mohan, N.; Aykut, B.; Usyk, M.; Torres, L.E.; et al. The Pancreatic Cancer Microbiome Promotes Oncogenesis by Induction of Innate and Adaptive Immune Suppression. Cancer Discov. 2018, 8, 403-416. [CrossRef] [PubMed]

18. Oh, J.; Weiderpass, E. Infection and Cancer: Global Distribution and Burden of Diseases. Ann. Glob. Health 2014, 80, 384-392. [CrossRef]

19. Yu, Q.; Jobin, C.; Thomas, R.M. Implications of the microbiome in the development and treatment of pancreatic cancer: Thinking outside of the box by looking inside the gut. Neoplasia 2021, 23, 246-256. [CrossRef]

20. Kalia, V.C.; Patel, S.K.S.; Cho, B.; Wood, T.K.; Lee, J. Emerging applications of bacteria as antitumor agents [published online ahead of print, 2021 May 11]. Semin. Cancer Biol. 2021, S1044-579X(21), 140. [CrossRef]

21. Youssef, O.; Lahti, L.; Kokkola, A.; Karla, T.; Tikkanen, M.; Ehsan, H.; Carpelan-Holmström, M.; Koskensalo, S.; Böhling, T.; Rautelin, H.; et al. Stool Microbiota Composition Differs in Patients with Stomach, Colon, and Rectal Neoplasms. Dig. Dis. Sci. 2018, 63, 2950-2958. [CrossRef]

22. Sarhadi, V.; Mathew, B.; Kokkola, A.; Karla, T.; Tikkanen, M.; Rautelin, H.; Lahti, L.; Puolakkainen, P.; Knuutila, S. Gut microbiota of patients with different subtypes of gastric cancer and gastrointestinal stromal tumors. Gut Pathog. 2021, 13, 11. [CrossRef]

23. Johns, M.S.; Petrelli, N.J. Microbiome and colorectal cancer: A review of the past, present, and future. Surg. Oncol. 2021, 37, 101560. [CrossRef] [PubMed]

24. Arsenijevic, T.; Nicolle, R.; Bouchart, C.; D’haene, N.; Demetter, P.; Puleo, F.; Van Laethem, J. Pancreatic Cancer Meets Human Microbiota: Close Encounters of the Third Kind. Cancers 2021, 13, 1231. [CrossRef]

25. Heim, S.; Mitelman, F. Cancer Cytogenetics, 4th ed.; Wiley Blackwell: Chichester, UK, 2015; pp. 386-388.

26. Corbo, V.; Mafficini, A.; Amato, E.; Scarpa, A. Pancreatic Cancer Genomics. In Cancer Genomics: Molecular Classification, Prognosis and Response Prediction; Pfeffer, U., Ed.; Springer: Dordrecht, The Netherlands, 2013; pp. $219-253$.

27. Chang, E.B.; Leung, P.S. Pancreatic Physiology. In The Gastrointestinal System; Springer: Dordrecht, The Netherlands, 2014; pp. 87-105. 
28. Adolph, T.E.; Mayr, L.; Grabherr, F.; Schwärzler, J.; Tilg, H. Pancreas-Microbiota Cross Talk in Health and Disease. Annu. Rev. Nutr. 2019, 39, 249-266. [CrossRef] [PubMed]

29. Gallo, R.L.; Kim, K.J.; Bernfield, M.; Kozak, C.A.; Zanetti, M.; Merluzzi, L.; Gennaro, R. Identification of CRAMP, a Cathelinrelated Antimicrobial Peptide Expressed in the Embryonic and Adult Mouse. J. Biol. Chem. 1997, 272, 13088-13093. [CrossRef] [PubMed]

30. Ahuja, M.; Schwartz, D.M.; Tandon, M.; Son, A.; Zeng, M.; Swaim, W.; Eckhaus, M.; Hoffman, V.; Cui, Y.; Xiao, B.; et al. Orai1-Mediated Antimicrobial Secretion from Pancreatic Acini Shapes the Gut Microbiome and Regulates Gut Innate Immunity. Cell Metab. 2017, 25, 635-646. [CrossRef]

31. Sun, J.; Furio, L.; Mecheri, R.; van der Does, A.; Lundeberg, E.; Saveanu, L.; Chen, Y.; van Endert, P.; Agerberth, B.; Diana, J. Pancreatic $\beta$-Cells Limit Autoimmune Diabetes via an Immunoregulatory Antimicrobial Peptide Expressed under the Influence of the Gut Microbiota. Immunity 2015, 43, 304-317. [CrossRef] [PubMed]

32. Perry, R.J.; Peng, L.; Barry, N.A.; Cline, G.W.; Zhang, D.; Cardone, R.L.; Petersen, K.F.; Kibbey, R.G.; Goodman, A.L.; Shulman, G.I. Acetate mediates a microbiome-brain- $\beta$-cell axis to promote metabolic syndrome. Nature 2016, 534, 213-217. [CrossRef]

33. Geller, L.T.; Barzily-Rokni, M.; Danino, T.; Jonas, O.H.; Shental, N.; Nejman, D.; Gavert, N.; Zwang, Y.; Cooper, Z.A.; Shee, K.; et al. Potential role of intratumor bacteria in mediating tumor resistance to the chemotherapeutic drug gemcitabine. Science 2017, 357, 1156-1160. [CrossRef]

34. Del Castillo, E.; Meier, R.; Chung, M.; Koestler, D.C.; Chen, T.; Paster, B.J.; Charpentier, K.P.; Kelsey, K.T.; Izard, J.; Michaud, D.S. The Microbiomes of Pancreatic and Duodenum Tissue Overlap and Are Highly Subject Specific but Differ between Pancreatic Cancer and Noncancer Subjects. Cancer Epidemiol. Biomark. Prev. 2019, 28, 370-383. [CrossRef]

35. Thomas, R.M.; Gharaibeh, R.Z.; Gauthier, J.; Beveridge, M.; Pope, J.L.; Guijarro, M.V.; Yu, Q.; He, Z.; Ohland, C.; Newsome, R.; et al. Intestinal microbiota enhances pancreatic carcinogenesis in preclinical models. Carcinogenesis (New York) 2018, 39, 1068-1078. [CrossRef]

36. Thomas, R.M.; Jobin, C. Microbiota in pancreatic health and disease: The next frontier in microbiome research. Nat. Rev. Gastroenterol. Hepatol. 2020, 17, 53-64. [CrossRef] [PubMed]

37. Kiss, B.; Mikó, E.; Sebő, É.; Toth, J.; Ujlaki, G.; Szabó, J.; Uray, K.; Bai, P.; Árkosy, P. Oncobiosis and Microbial Metabolite Signaling in Pancreatic Adenocarcinoma. Cancers 2020, 12, 1068. [CrossRef]

38. Hanahan, D.; Weinberg, R.A. Hallmarks of cancer: The next generation. Cell 2011, 144, 646-674. [CrossRef]

39. Hanahan, D.; Weinberg, R.A. The hallmarks of cancer. Cell 2000, 100, 57-70. [CrossRef]

40. Gopalakrishnan, V.; Helmink, B.A.; Spencer, C.N.; Reuben, A.; Wargo, J.A. The Influence of the Gut Microbiome on Cancer, Immunity, and Cancer Immunotherapy. Cancer Cell 2018, 33, 570-580. [CrossRef]

41. Stolzenberg-Solomon, R.Z.; Dodd, K.W.; Blaser, M.J.; Virtamo, J.; Taylor, P.R.; Albanes, D. Tooth loss, pancreatic cancer, and Helicobacter pylori. Am. J. Clin. Nutr. 2003, 78, 176-181. [CrossRef]

42. Mitsuhashi, K.; Nosho, K.; Sukawa, Y.; Matsunaga, Y.; Ito, M.; Kurihara, H.; Kanno, S.; Igarashi, H.; Naito, T.; Adachi, Y.; et al. Association of Fusobacterium species in pancreatic cancer tissues with molecular features and prognosis. Oncotarget 2015, 6, 7209-7220. [CrossRef]

43. Ahn, J.; Segers, S.; Hayes, R.B. Periodontal disease, porphyromonas gingivalis serum antibody levels and orodigestive cancer mortality. Carcinogenesis 2012, 33, 1055-1058. [CrossRef] [PubMed]

44. Michaud, D.S. Role of bacterial infections in pancreatic cancer. Carcinogenesis 2013, 34, 2193-2197. [CrossRef]

45. Hayashi, C.; Gudino, C.V.; Gibson, F.C.; Genco, C.A. Pathogen-induced inflammation at sites distant from oral infection: Bacterial persistence and induction of cell-specific innate immune inflammatory pathways. Mol. Oral Microbiol. 2010, 25, 305-316. [CrossRef] [PubMed]

46. Vogtmann, E.; Han, Y.; Caporaso, J.G.; Bokulich, N.; Mohamadkhani, A.; Moayyedkazemi, A.; Hua, X.; Kamangar, F.; Wan, Y.; Suman, S.; et al. Oral microbial community composition is associated with pancreatic cancer: A case-control study in Iran. Cancer Med. 2020, 9, 797-806. [CrossRef]

47. Fan, X.; Alekseyenko, A.V.; Wu, J.; Peters, B.A.; Jacobs, E.J.; Gapstur, S.M.; Purdue, M.P.; Abnet, C.C.; Stolzenberg-Solomon, R.; Miller, G.; et al. Human oral microbiome and prospective risk for pancreatic cancer: A population-based nested case-control study. Gut 2018, 67, 120-127. [CrossRef]

48. Torres, P.J.; Fletcher, E.M.; Gibbons, S.M.; Bouvet, M.; Doran, K.S.; Kelley, S.T. Characterization of the salivary microbiome in patients with pancreatic cancer. PeerJ 2015, 3, e1373. [CrossRef] [PubMed]

49. Lu, H.; Ren, Z.; Li, A.; Li, J.; Xu, S.; Zhang, H.; Jiang, J.; Yang, J.; Luo, Q.; Zhou, K.; et al. Tongue coating microbiome data distinguish patients with pancreatic head cancer from healthy controls. J. Oral Microbiol. 2019, 11, 1563409. [CrossRef] [PubMed]

50. Farrell, J.J.; Zhang, L.; Zhou, H.; Chia, D.; Elashoff, D.; Akin, D.; Paster, B.J.; Joshipura, K.; Wong, D.T. Variations of oral microbiota are associated with pancreatic diseases including pancreatic cancer. Gut 2012, 61, 582-588. [CrossRef]

51. Pandya, G.; Kirtonia, A.; Singh, A.; Goel, A.; Mohan, C.D.; Rangappa, K.S.; Pandey, A.K.; Kapoor, S.; Tandon, S.; Sethi, G.; et al. A comprehensive review of the multifaceted role of the microbiota in human pancreatic carcinoma [published online ahead of print, 2021 May 26]. Semin. Cancer Biol. 2021, S1044-579X, 157. [CrossRef]

52. Aykut, B.; Pushalkar, S.; Chen, R.; Li, Q.; Abengozar, R.; Kim, J.I.; Shadaloey, S.A.; Wu, D.; Preiss, P.; Verma, N.; et al. The fungal mycobiome promotes pancreatic oncogenesis via activation of MBL. Nature 2019, 574, 264-267. [CrossRef] [PubMed] 
53. Riquelme, E.; Maitra, A.; McAllister, F. Immunotherapy for Pancreatic Cancer: More Than Just a Gut Feeling. Cancer Discov. 2018, 8, 386-388. [CrossRef]

54. Chakladar, J.; Kuo, S.Z.; Castaneda, G.; Li, W.T.; Gnanasekar, A.; Yu, M.A.; Chang, E.Y.; Wang, X.Q.; Ongkeko, W.M. The Pancreatic Microbiome is Associated with Carcinogenesis and Worse Prognosis in Males and Smokers. Cancers 2020, $12,2672$. [CrossRef]

55. Nejman, D.; Livyatan, I.; Fuks, G.; Gavert, N.; Zwang, Y.; Geller, L.T.; Rotter-Maskowitz, A.; Weiser, R.; Mallel, G.; Gigi, E.; et al. The human tumor microbiome is composed of tumor type-specific intracellular bacteria. Science 2020, 368, 973-980. [CrossRef]

56. Bao, Y.; Spiegelman, D.; Li, R.; Giovannucci, E.; Fuchs, C.S.; Michaud, D.S. History of Peptic Ulcer Disease and Pancreatic Cancer Risk in Men. Gastroenterology 2010, 138, 541-549. [CrossRef]

57. Nilsson, H.; Stenram, U.; Ihse, I.; Wadstrom, T. Helicobacter species ribosomal DNA in the pancreas, stomach and duodenum of pancreatic cancer patients. World J. Gastroenterol. WJG 2006, 12, 3038-3043. [CrossRef] [PubMed]

58. Li, S.; Fuhler, G.M.; Bn, N.; Jose, T.; Bruno, M.J.; Peppelenbosch, M.P.; Konstantinov, S.R. Pancreatic cyst fluid harbors a unique microbiome. Microbiome 2017, 5, 147. [CrossRef] [PubMed]

59. Gaiser, R.A.; Halimi, A.; Alkharaan, H.; Lu, L.; Davanian, H.; Healy, K.; Hugerth, L.W.; Ateeb, Z.; Valente, R.; Fernández Moro, C.; et al. Enrichment of oral microbiota in early cystic precursors to invasive pancreatic cancer. Gut 2019, 68, 2186-2194. [CrossRef]

60. Half, E.; Keren, N.; Reshef, L.; Dorfman, T.; Lachter, I.; Kluger, Y.; Reshef, N.; Knobler, H.; Maor, Y.; Stein, A.; et al. Fecal microbiome signatures of pancreatic cancer patients. Sci. Rep. 2019, 9, 16801-16804. [CrossRef]

61. Ren, Z.; Jiang, J.; Xie, H.; Li, A.; Lu, H.; Xu, S.; Zhou, L.; Zhang, H.; Cui, G.; Chen, X.; et al. Gut microbial profile analysis by MiSeq sequencing of pancreatic carcinoma patients in China. Oncotarget 2017, 8, 95176-95191. [CrossRef] [PubMed]

62. Cougnoux, A.; Dalmasso, G.; Martinez, R.; Buc, E.; Delmas, J.; Gibold, L.; Sauvanet, P.; Darcha, C.; Déchelotte, P.; Bonnet, M.; et al. Bacterial genotoxin colibactin promotes colon tumour growth by inducing a senescence-associated secretory phenotype. Gut 2014, 63, 1932-1942. [CrossRef]

63. Maekawa, T.; Fukaya, R.; Takamatsu, S.; Itoyama, S.; Fukuoka, T.; Yamada, M.; Hata, T.; Nagaoka, S.; Kawamoto, K.; Eguchi, H.; et al. Possible involvement of Enterococcus infection in the pathogenesis of chronic pancreatitis and cancer. Biochem. Biophys. Res. Commun. 2018, 506, 962-969. [CrossRef]

64. Kohi, S.; Macgregor-Das, A.; Dbouk, M.; Yoshida, T.; Chuidian, M.; Abe, T.; Borges, M.; Lennon, A.M.; Shin, E.J.; Canto, M.I.; et al. Alterations in the Duodenal Fluid Microbiome of Patients With Pancreatic Cancer [published online ahead of print, 2020 Nov 5]. Clin. Gastroenterol. Hepatol. 2020. [CrossRef]

65. Stolzenberg-Solomon, R.Z.; Blaser, M.J.; Limburg, P.J.; Perez-Perez, G.; Taylor, P.R.; Virtamo, J.; Albanes, D. Helicobacter pylori Seropositivity as a Risk Factor for Pancreatic Cancer. JNCI J. Natl. Cancer Inst. 2001, 93, 937-941. [CrossRef]

66. Guo, Y.; Liu, W.; Wu, J. Helicobacter pylori infection and pancreatic cancer risk: A meta-analysis. J. Cancer Res. Ther. 2016, 12, C229-C232. [CrossRef]

67. Kunovsky, L.; Dite, P.; Jabandziev, P.; Dolina, J.; Vaculova, J.; Blaho, M.; Bojkova, M.; Dvorackova, J.; Uvirova, M.; Kala, Z.; et al. Helicobacter pylori infection and other bacteria in pancreatic cancer and autoimmune pancreatitis. World J. Gastrointest. Oncol. 2021, 13, 835-844. [CrossRef]

68. Mei, Q.X.; Huang, C.L.; Luo, S.Z.; Zhang, X.M.; Zeng, Y.; Lu, Y.Y. Characterization of the duodenal bacterial microbiota in patients with pancreatic head cancer vs. healthy controls. Pancreatology 2018, 18, 438-445. [CrossRef] [PubMed]

69. Friedlander, S.Y.G.; Chu, G.C.; Snyder, E.L.; Girnius, N.; Dibelius, G.; Crowley, D.; Vasile, E.; DePinho, R.A.; Jacks, T. ContextDependent Transformation of Adult Pancreatic Cells by Oncogenic K-Ras. Cancer Cell 2009, 16, 379-389. [CrossRef]

70. Tijeras-Raballand, A.; Hilmi, M.; Astorgues-Xerri, L.; Nicolle, R.; Bièche, I.; Neuzillet, C. Microbiome and pancreatic ductal adenocarcinoma. Clin. Res. Hepatol. Gastroenterol. 2021, 45, 101589. [CrossRef]

71. Huang, H.; Daniluk, J.; Liu, Y.; Chu, J.; Li, Z.; Ji, B.; Logsdon, C.D. Oncogenic K-Ras requires activation for enhanced activity. Oncogene 2014, 33, 532-535. [CrossRef]

72. Torphy, R.J.; Fujiwara, Y.; Schulick, R.D. Pancreatic cancer treatment: Better, but a long way to go. Surg. Today 2020, 50, 1117-1125. [CrossRef]

73. Zeng, S.; Pöttler, M.; Lan, B.; Grützmann, R.; Pilarsky, C.; Yang, H. Chemoresistance in Pancreatic Cancer. Int. J. Mol. Sci. 2019, 20, 4504. [CrossRef]

74. Zhang, X.; Liu, Q.; Liao, Q.; Zhao, Y. Pancreatic Cancer, Gut Microbiota, and Therapeutic Efficacy. J. Cancer 2020, 11, $2749-2758$. [CrossRef] [PubMed]

75. Ramos, A.; Hemann, M.T. Drugs, Bugs, and Cancer: Fusobacterium nucleatum Promotes Chemoresistance in Colorectal Cancer. Cell 2017, 170, 411-413. [CrossRef] [PubMed]

76. An, J.; Ha, E. Combination therapy of Lactobacillus plantarum supernatant and 5-fluouracil increases chemosensitivity in colorectal cancer cells. J. Microbiol. Biotechnol. 2016, 26, 1490-1503. [CrossRef] [PubMed]

77. Daillère, R.; Vétizou, M.; Waldschmitt, N.; Yamazaki, T.; Isnard, C.; Poirier-Colame, V.; Duong, C.M.; Flament, C.; Lepage, P.; Roberti, M.; et al. Enterococcus hirae and Barnesiella intestinihominis Facilitate Cyclophosphamide-Induced Therapeutic Immunomodulatory Effects. Immunity 2016, 45, 931-943. [CrossRef]

78. Carpenter, E.; Nelson, S.; Bednar, F.; Cho, C.; Nathan, H.; Sahai, V.; Magliano, M.P.; Frankel, T.L. Immunotherapy for pancreatic ductal adenocarcinoma. J. Surg. Oncol. 2021, 123, 751-759. [CrossRef] 
79. Schizas, D.; Charalampakis, N.; Kole, C.; Economopoulou, P.; Koustas, E.; Gkotsis, E.; Ziogas, D.; Psyrri, A.; Karamouzis, M.V. Immunotherapy for pancreatic cancer: A 2020 update. Cancer Treat. Rev. 2020, 86, 102016. [CrossRef] [PubMed]

80. Rezasoltani, S.; Yadegar, A.; Asadzadeh Aghdaei, H.; Reza Zali, M. Modulatory effects of gut microbiome in cancer immunotherapy: A novel paradigm for blockade of immune checkpoint inhibitors. Cancer Med. 2021, 10, 1141-1154. [CrossRef]

81. Sethi, V.; Vitiello, G.A.; Saxena, D.; Miller, G.; Dudeja, V. The Role of the Microbiome in Immunologic Development and its Implication For Pancreatic Cancer Immunotherapy. Gastroenterology 2019, 156, 2097-2115.e2. [CrossRef] [PubMed]

82. Liu, P.; Wang, Y.; Yang, G.; Zhang, Q.; Meng, L.; Xin, Y.; Jiang, X. The role of short-chain fatty acids in intestinal barrier function, inflammation, oxidative stress, and colonic carcinogenesis. Pharmacol. Res. 2021, 165, 105420. [CrossRef]

83. Mullins, T.D.; Kern, H.F.; Metzgar, R.S. Ultrastructural Differentiation of Sodium Butyrate-Treated Human Pancreatic Adenocarcinoma Cell Lines. Pancreas 1991, 6, 578-587. [CrossRef]

84. Asai, Y.; Itoi, T.; Sugimoto, M.; Sofuni, A.; Tsuchiya, T.; Tanaka, R.; Tonozuka, R.; Honjo, M.; Mukai, S.; Fujita, M.; et al. Elevated Polyamines in Saliva of Pancreatic Cancer. Cancers 2018, 10, 43. [CrossRef]

85. Arruabarrena-Aristorena, A.; Zabala-Letona, A.; Carracedo, A. Oil for the cancer engine: The cross-talk between oncogenic signaling and polyamine metabolism. Sci. Adv. 2018, 4, eaar2606. [CrossRef]

86. Casero, J.; Robert, A.; Murray Stewart, T.; Pegg, A.E. Polyamine metabolism and cancer: Treatments, challenges and opportunities. Nat. Rev. Cancer 2018, 18, 681-695. [CrossRef]

87. Tofalo, R.; Cocchi, S.; Suzzi, G. Polyamines and gut microbiota. Front. Nutr. 2019, 6, 16. [CrossRef]

88. Mendez, R.; Kesh, K.; Arora, N.; Di Martino, L.; McAllister, F.; Merchant, N.; Banerjee, S.; Banerjee, S. Microbial dysbiosis and polyamine metabolism as predictive markers for early detection of pancreatic cancer. Carcinogenesis 2020, 41, 561-570. [CrossRef]

89. Avila-Calderón, E.D.; Ruiz-Palma, M.D.S.; Aguilera-Arreola, M.G.; Velázquez-Guadarrama, N.; Ruiz, E.A.; Gomez-Lunar, Z.; Witonsky, S.; Contreras-Rodríguez, A. Outer Membrane Vesicles of Gram-Negative Bacteria: An Outlook on Biogenesis. Front. Microbiol. 2021, 12, 557902. [CrossRef]

90. Kadosh, E.; Snir-Alkalay, I.; Venkatachalam, A.; May, S.; Lasry, A.; Elyada, E.; Zinger, A.; Shaham, M.; Vaalani, G.; Mernberger, M.; et al. The gut microbiome switches mutant p53 from tumour-suppressive to oncogenic. Nature 2020, 586, 133-138. [CrossRef]

91. Dieterich, W.; Schink, M.; Zopf, Y. Microbiota in the Gastrointestinal Tract. Med. Sci. 2018, 6, 116. [CrossRef] [PubMed]

92. Sarhadi, V.; Lahti, L.; Saberi, F.; Youssef, O.; Kokkola, A.; Karla, T.; Tikkanen, M.; Rautelin, H.; Puolakkainen, P.; Salehi, R.; et al. Gut Microbiota and Host Gene Mutations in Colorectal Cancer Patients and Controls of Iranian and Finnish Origin. Anticancer Res. 2020, 40, 1325-1334. [CrossRef] [PubMed]

93. Janney, A.; Powrie, F.; Mann, E.H. Host-microbiota maladaptation in colorectal cancer. Nature 2020, 585, 509-517. [CrossRef] [PubMed]

94. Shirazi, M.S.R.; Al-Alo, K.Z.K.; Al-Yasiri, M.H.; Lateef, Z.M.; Ghasemian, A. Microbiome Dysbiosis and Predominant Bacterial Species as Human Cancer Biomarkers. J. Gastrointest. Cancer 2020, 51, 725-728. [CrossRef]

95. Öğrendik, M. Periodontal Pathogens in the Etiology of Pancreatic Cancer. Gastrointest. Tumors 2017, 3, 125-127. [CrossRef]

96. Gnanasekaran, J.; Binder Gallimidi, A.; Saba, E.; Pandi, K.; Eli Berchoer, L.; Hermano, E.; Angabo, S.; Makkawi, H.A.; Khashan, A.; Daoud, A.; et al. Intracellular Porphyromonas gingivalis Promotes the Tumorigenic Behavior of Pancreatic Carcinoma Cells. Cancers 2020, 12, 2331. [CrossRef]

97. Guo, W.; Zhang, Y.; Guo, S.; Mei, Z.; Liao, H.; Dong, H.; Wu, K.; Ye., H.; Zhang., Y.; Zhu., Y.; et al. Tumor microbiome contributes to an aggressive phenotype in the basal-like subtype of pancreatic cancer. Commun. Biol. 2021, 4, 1019. [CrossRef] 